\title{
PEMASARAN PARIWISATA KOTA BOGOR MELALUI MEDIA PROMOSI WEBSITE
}

\author{
Asep Candra Hidayat \\ Institut Ilmu Sosial dan Manajemen Stiami \\ asep.candra@yahoo.co.id
}

\begin{abstract}
Abstrak.Untuk mensukseskan pwiriwisata di kota Bogor tersebut, pemerintah PEMDA Kotamadya Bogor saat ini sedang gencar melakukan kegiatan promosi, diantaranya melalui Web Site. Untuk melihat sejauh mana keberhasilan upaya promosi melalui Website, maka dilakukan penelitian terhadap masyarakat Kota Bogor untuk menilai persepsi mereka.

Pendekatan yang digunakan dalam penelitian ini adalah pendekatan kuantitatif, yaitu dengan menggunakan perhitungan dengan skala Likert. Populasi meliputi wisatawan dan calon wisatawan yang telah/pernah, dan akan berkunjung ke Kota Bogor, baik di Kota Bogor maupun luar kota Bogor. Adapun jumlah populasi tidak dapat diperkirakan dengan pasti. Teknik pengambilan sampel dalam penelitian ini adalah menggunakan metode accidental sampling, dengan jumlah sample diambil sebanyak 33 orang sesuai jumlah orang yang berhasil ditemui dan bersedia mengisi kuesioner saat dilakukan penelitian. Teknik Pengumpulan Data dilakukan dengan 2 cara yaitu lewat kuesioner dan dokumentasi. Teknik Analisis Data menggunakan rumus nilai rata-rata

Hasil penelitian menunjukkan bahwa pemasaran pariwisata Kota Bogor melalui Web Site sudah sangat baik, hal tersebut terlihat dari nilai skor rata-rata kualitas pelayanan sebesar 3,87 yang termasuk kategori baik. Namun demikian masih ada beberapa komponen penilaian yang perlu ditingkatkan yaitu "Interaksi Pasca Kunjungan Wisata" serta "Informasi Wisata Lengkap"
\end{abstract}

Kata kunci: Pemasaran Pariwisata via Website

Abstract To succeed pwiriwisata in the city of Bogor, the local government of Bogor City Government is currently intensively doing promotional activities, including through the Web Site. To see the extent of the success of promotional efforts through the Website, then conducted a study on the people of Bogor City to assess their perceptions.

The approach used in this research is quantitative approach, that is by using calculation with Likert scale. The population includes tourists and potential tourists who have / ever, and will visit the city of Bogor, both in the city of Bogor and outside the city of Bogor. The number of population can not be predicted with certainty. Sampling technique in this research is using accidental sampling method, with the number of samples taken as many as 33 people according to the number of people who successfully met and willing to fill out the questionnaire when done research. Data Collection Technique done in 2 way that is through questioner and documentation. Data Analysis Technique uses the average value formula

The results showed that the marketing of Bogor City tourism through the Web Site is very good, it can be seen from the average score of service quality of 3.87 are included in either category. Nevertheless, there are still some assessment components that need to be improved: "Post-Visit Trip Interaction" and "Full Tour Information"

Keywords: Tourism Marketing via Website

\section{PENDAHULUAN}

Untuk meningkatkan obyek wisata yang ada di Kota Bogor, Dinas Kebudayaan dan Pariwisata Kota Bogor menggelar pelatihan strategi pemasaran pariwisata. Hal ini ditujukan kepada para pengelola hotel dan travel serta pemandu wisata. Artinya, ada keseriusan di bidang pemasaran pariwisata yang digenjot oleh pemerintah setempat dalam rangka mengembangkan layanan yang profesional. 
Selain itu, pengunjung wisata yang ada di Kota Bogor pada dasarnya memiliki perkembangan yang luar biasa, terutama ketika masa liburan tiba. Oleh karena itu, secara tidak langsung pola perkembangan pariwisata ke arah depan harus sesuai dengan visi dan misi yang komprehensif. Inilah yang menjadikan Kota Bogor memiliki minat dan kerjasama yang baik dari para stakeholter. Terlebih saat ini keberadaan Kota Bogor sudah memiliki obyek wisata yang berbasis alam seperti Kebun Raya Bogor, cifor, dan situs.

Pangsa pasar yang dibidik secara baik, pada dasarnya mampu menciptakan peluang yang baik di bidang lapangan pekerjaan. Sehingga melalui kegiatan ini pemandu wisata di Kota Bogor dapat benar-benar melayani para wisatawan, terutama bagi mereka yang bersinggungan dengan hotel dan travel. Sebab kedua elemen tersebut akan senantiasa bersinergis dengan masyarakat lokal selaku pelaku usaha dalam memenuhi kebutuhan yang belum tersedia.

Untuk itu, obyek wisata yang ada di Kota Bogor dari tahun ke tahun harus memiliki target mengundang wisatawan dari berbagai daerah dosmestik maupun mancanegara. Hal ini dilakukan sebagai langkah dalam menggenjot Pendapat Asli Daerah (PAD), walaupun Dinas Kebudayaan dan Pariwisata Kota Bogor selaku pemerintah tidak langsung menerima pemasukan tersebut. Namun, dengan ada pendapatan yang diperoleh secara langsung pemerintah dapat mengklaim keberhasilan dalam mengejar wisatawan untuk datang ke Kota Bogor.

Langkah strategis tersebut adalah bagian dari kegiatan pemasaran yang dapat dilakukan oleh pemerintah Kota Bogor. Bahkan sudah semestinya ada dukungan dari pihak swasta yang memadukan dan mensinergiskan antara pelaku wisata dengan masyarakat lokal dalam menarik minat wisatawan yang berkunjung, terutama untuk rutinitas mereka kembali berkunjung Ke Kota Bogor. Tentu tidak mudah, karena kepuasan yang diterima juga berpengaruh pada mau tidaknya mereka datang.

Apalagi ada target dari Kota Bogor untuk dapat meningkatkan pelayanan yang profesional sehingga dapat mengejr wisatawan dari mancanegara. Hal ini juga membantu pemerintah pusat yang memiliki target menggaet 20 juta wisatawan mancanegara di 2019. Namun, lebih dari itu, pola lama tinggal di destinasi wisata Kota Bogor juga perlu dipertahankan karena pemasaran dengan model tersebut pendapatan daerah terus mengalir. Tidak terkecuali masyarakat dengan tingkat ekonomi yang akan naik.

Tidak dipungkiri pemasaran pariwisata untuk wilayah Kota Bogor juga bersinggungan dengan kebudayaan dan tradisi yang memiliki potensi lain. Biasanya satu daerah dengan daerah yang lain tersebut mempunyai perbedaan yang mencolok dan begitu pula di Kota Bogor. Artinya, beragam suku etnis dan beberapa tempat wisata menjadikan kota Bogor sebagai kota transit bagi wisatawan asing maupun domestik. Adanya interaksi masyarakat lokal dengan wisatawan menyebabkan perbedaan pola hidup termasuk jenis makanan yang dikonsumsi.

Seiring dengan perkembangan tingkat gaya hidup di masyarakat dan keanekaragaman selera konsumen, perkembangan jenis makanan jadi semakin beragam. Berkembangnya beragam jenis restoran di kota Bogor, merupakan reaksi atas beragamnya selera konsumen. Disamping itu wisata-wisata lainnya tak kalah menariknya seperti wisata eko wisata, wisata bisnis, wisata religi, wisata kuliner, wisata khusus dll

Untuk mensukseskan pwiriwisata di kota Bogor tersebut, pemerintah PEMDA Kotamadya Bogor saat ini sedang gencar melakukan kegiatan promosi, diantaranya melalui Web Site. Untuk melihat sejauh mana keberhasilan upaya promosi melalui We site, maka maka melakukan penelitian terhadap masyarakat Kota Bogor untuk menilai persepsi mereka.

\section{Tujuan Dan Manfaat Penelitian}

Dari penelitian yang dilakukan, penulis memiliki tujuan untuk mengetahui sebaik apa promosi pariwisata yang dilakukan di kota bogor melalui Web Site.

Manfaat yang diharapkan dari penelitian ini adalah model yang dihasilkan dapat diaplikasikan secara luas. Namun, secara spesifik, manfaat diharapkan:

1. Bagi bidang ilmu pengetahuan. Penelitian ini menjadi bahan penambah wawasan dan 
pengetahuan bagi masyarakat luas, khususnya dalam bidang faktor hospitaliti pariwisata. Karena pengaplikasian model dapat menjadi salah satu alternatif pengembangan dari faktor hospitaliti pada suatu destinasi pariwisata yang ada secara optimal.

2. Bagi peneliti selanjutnya. Penelitian ini dapat menjadi bahan referensi bagi pihakpihak yang hendak mengadakan penelitian lanjutan mengenai faktor hospitaliti yang pada gilirannya masyarakat lokal dapat memetik manfaat secara ekonomi dengan optimal.

\section{KAJIAN PUSTAKA}

Faktor yang ada pada hospitaliti pariwisata pada dasarnya mengacu dari teori penawaran dan permintaan yang disediakan oleh pengelola destinasi wisata. Sukirno (1985: 51) menyampaikan bahwa secara sederhana teori penawaran dan permintaan membahas mengenai interaksi antara penjual dan pembeli dalam menentukan harga suatu barang dan jumlah barang yang akan ditawarkan. Sehingga bisnis pariwisata sering disebut sebagai sebuah industri jasa karena adanya serangkaian proses aktivitas atau kegiatan produksi yang menghasilkan nilai tambah dan produknya bersifat tidak nyata, serta menawarkan keramahtamahan (hospitality) (Sunaryo, 2013).

Keterkaitan sistemik dari berbagai aktivitas kepariwisataan menggambarkan interaksi antara dua komponen pokok kepariwisataan yaitu komponen produk dan komponen pasar. Bagian komponen produk wisata yang juga sering disebut sebagai komponen pokok sebuah destinasi antara lain daya tarik wisata yang menawakan keindahan alam, keunikan budaya atau minat khusus, fasilitas pariwisata seperti akomodasi atau rumah makan, aksesibilitas, moda transpotasi yang tersedia, fasilitas pendukung lainnya, dan masyarakat sebagai tuan rumah destinasi.

Sedangkan dari bagian komponen pasar biasanya dibagi menjadi dua segmen yaitu pasar wisatawan domestik dan pasar wisatawan internasional. Pada komponen ini sangat dipengaruhi oleh faktor-faktor dari wisatawan seperti motivasi dan faktor penentu pribadinya dalam memilih suatu aktivitas pariwisata di suatu destinasi. Usaha akomodasi merupakan bagian dari komponen produk suatu destinasi dalam rangka memenuhi kebutuhan komponen pasar. Dalam mengembangkan pariwisata di suatu daerah sangat tergantung kepada kemampuan perencana dalam mengintegrasikan kedua sisi tersebut secara berimbang ke dalam sebuah rencana pengembangan pariwisata.

Dalam arti, bagaimana menyeimbangkan antara kedua sisi tersebut, agar tidak terjadi kelebihan produk sedangkan kunjungan wisatawan semakin menurun. Begitu pula halnya dengan pembangunan sarana akomodasi di Kota Bogor, agar sesuai dengan kunjungan wisatawan sehingga dapat meningkatkan tingkat hunian hotel atau homestay dan akan lebih bagus bila diikuti dengan lama tinggal dan pengeluaran wisatawan yang semakin banyak.

Namun saat ini, perkembangan usaha wisata tersebut juga menimbulkan masalah baru yaitu adanya persaingan antar-pengusaha hotel. Persaingan hotel tidak saja terjadi antara usaha pariwisata, namun juga sumber daya yang ada di dalam usaha wisata itu sendiri. Dengan demikian, perlu adanya suatu strategi dalam mengantispasi situasi semacam ini. Selain melakukan promosi kepada pasar yang dituju, bekerja sama dengan berbagai pihak yang memiliki kepentingan di dalam akomodasi dan transportasi juga melakukan koordinasi yang baik sehingga sangat penting untuk selalu meningkatkan kemampuan dalam mengelola usaha wisata sesuai perkembangan zaman yang diminati oleh wisatawan.

Kriteria dalam memanfaatkan ruang sebagai pemenuhan faktor kawasan pariwisata, maka disediakan juga unsur sarana dan prasarana. Dimana terdapat objek dan daya tarik wisata yang diatur oleh kebijakan pemerintah sesuai dengan kapasitas waktu yang dibutuhkan. Ini pula yang menjadi daya tarik Kota Bogor ketika sudah bersinggungan dengan strategi menarik minat wisatawan untuk berkunjung. Salah satu strategi Pemda Kota Bogor untuk menarik wisatawan adalah denga upaya promosi Web Site. 
Pariwisata adalah perjalanan dari satu tempat ke tempat lain, bersifat sementara, dilakukan perorangan maupun kelompok, sebagai usaha mencari keseimbangan atau keserasian dan kebahagiaan dengan lingkungan hidup dalam dimensi sosial, budaya, alam, dan ilmu Suatu perjalanan dianggap sebagai perjalanan wisata jika memenuhi 3 persyaratan, yaitu: harus bersifat sementara, harus bersifat sukarela dalam arti tidak terjadi karena paksaan, dan tidak bekerja yang sifatnya menghasilkan upah.

Menurut Hunziker dan Kraff (1987) pengertian pariwisata adalah Tourism is the total relationship and phenomena linked with the stay of a foreigner at a locality, provided that they do not settle there to exercise a major, permanent or temporary remunerated activity. Artinya pariwisata adalah total fenomena yang terkait dengan orang asing yang tinggal di suatu daerah, asalkan tidak menetapkan disana untuk pelatihan utama (bekerja), aktivitas permanen atau sementara yang berbiaya besar.

Sedangkan pemasaran menurut Philip Kotler mendefenisikan marketing mix atau bauran pemasaran sebagai serangkaian variabel yang dapat dikontrol dan tingkat variabel yang digunakan oleh perusahaan untuk mempengaruhi pasaran yang menjadi sasaran. Keempat unsur atau variabel bauran pemasaran (Marketing mix) tersebut atau yang disebut four p's, adalah sebagai berikut: 1. Strategi Produk 2. Strategi Harga 3. Strategi Penyaluran / Distribusi 4. Strategi Promosi Marketing mix atau bauran pemasaran sangat penting diperhatikan pada saat awal pembentukan bisnis restoran atau rumah makan. Bisnis restoran atau rumah makan seharusnya ditangani dari biaya makanan (food cost), pekerja, sewa (jika lokasi usaha bukan milik pribadi), promosi dan iklan, kualitas makanan, pelayanan pelanggan, keuntungan dan tentunya sikap untuk melanjutkan tipe bisnis ini.

Untuk itu memerlukan media promosi seperti website e-commerce guna untuk menunjukan potensi wisata yang ada seperti yang diungkapkan oleh Madcoms (2008), bahwa website adalah sebutan bagi sekelompok halaman web (web page), dan umumnya merupakan bagian dari suatu domain (domain name), atau subdomain dalam World Wide Web (WWW) di internet. WWW terdiri dari seluruh situs web yang tersedia kepada publik. Kemudian dilengkapi dengan E-commerce untuk melakukan proses pembelian dan penjualan jasa dan barangbarang secara elektronik dengan transaksi bisnis terkomputerisasi menggunakan internet, jaringan, dan teknologi digital lain. $E-$ Commerce juga meliputi aktivitas yang mendukung transaksi pasar, seperti iklan, pemasaran, layanan pelanggan, pengiriman barang pesanan, dan pembayaran (C. Laudon dan P. Laudon, 2005)

\section{Kerangka Pemikiran}

Untuk meningkatkan jumlah kunjungan wisatawan dapat ditempuh dengan berbagai cara, salah satu diantaranya dengan promosi pemasaran melalui web site. Kualitas materi promo web site yang baik (komunikatif dan interantif) berdampak terhadap daya Tarik calon wisatawan, sehingga semakin baik kualitas materi promo web site, maka diharapkan semakin banyak pula calon wisatawan yang tertarik dan kemudian menjadi wisatawan.

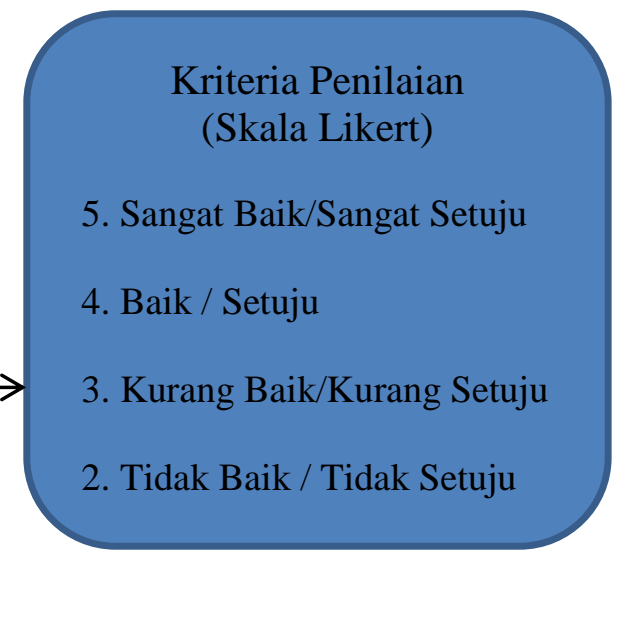

Model Konseptual

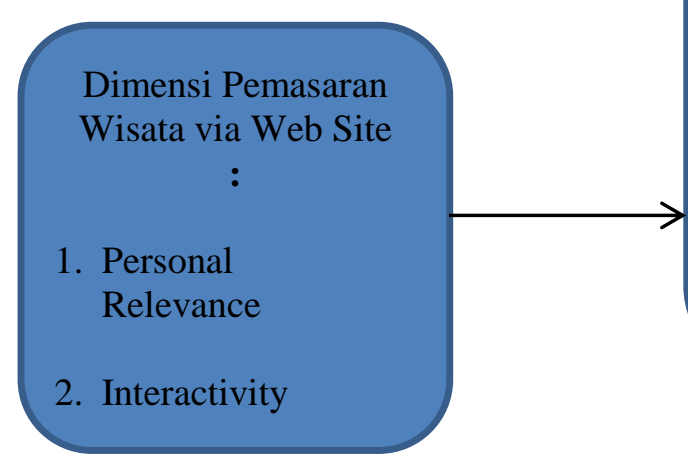

Gambar Model Penelitian 


\section{METODOLOGI PENELITIAN}

\section{A. Jenis Penelitian}

Penelitian ini merupakan penelitian deskriptif kuantitatif. Penelitian ini mencoba untuk mengetahui sebaik apa promosi/marketing pariwisata yang dilakukan PEMDA kota Bogor melalui Web Site. Pendekatan yang digunakan dalam penelitian ini adalah pendekatan kuantitatif, yaitu dengan menggunakan perhitungan dengan skala Likert.

\section{B. Jenis dan Teknik Pengumpulan Data}

Pendekatan yang digunakan dalam penelitian ini adalah pendekatan survei yaitu penelitian yang mengambil sampel dari satu populasi dan menggunakan kuesioner sebagai alat pengumpulan data yang pokok

\section{Populasi dan Sampel}

\section{Populasi}

Populasi adalah keseluruhan subyek penelitian (Arikunto, 2006: 130). Dengan menetapkan populasi, ini dimaksudkan agar suatu penelitian dapat mengukur sesuatu sesuai dengan kasusnya dan tidak berlebihan dengan populasi yang diacu.

Adapun jumlah populasi meliputi cwisatawan dan calon wisatawan yang telah/pernah, dan akan berkunjung ke Kota Bogor, baik di Kota Bogor maupun luar kota Bogor. Adapun jumlah populasi tidak dapat diperkirakan dengan pasti

\section{Sampel}

Yang dimaksud dengan sampel adalah sebagian atau wakil populasi yang diteliti (Arikunto, 2006: 131). Sesuai dengan pemahaman diatas, maka sampel dalam penelitian ini adalah sebagian atau wakil yang sudah ditentukan. Teknik pengambilan sampel dalam penelitian ini adalah menggunakan metode accidental sampling.
Menurut Sugiyono (2005:53) accidental sampling adalah teknik pengambilan sampel secara tidak sengaja atau secara acak terhadap sample yang kebetulan ketemu langsung. Adapun jumlah sample diambil sebanyak 33 orang sesuai jumlah orang yang berhasil ditemui dan bersedia mengisi kuesioner saat dilakukan penelitian.

\section{Teknik Pengumpulan Data}

Pengumpulan data dilakukan dengan 2 cara yaitu :

a. Kuesioner

Kuesioner merupakan teknik pengumpulan datayang dilakukan dengan cara memberi seperangkatpertanyaan atau pernyataan tertulis kepada responden untuk dijawabnya (Sugiyono, 2005: 135). Sehubungandengan penelitian ini peneliti, menyebarkan kuesionerkepada responden.

\section{b. Dokumentasi}

Dokumentasi adalah mencari data mengenai hal-hal atau variabel yang berupa catatan, transkip, buku, suratkabar, majalah, prasasti, notulen rapat, lengger, agenda dansebagainya (Arikunto, 2006: 231).Dalam penelitian ini dilakukan dengan melihat majalah, brosur dan internet yang berhubungan dengan motifasi untuk memperoleh landasan teori dan mendapatkan data yang dapat menunjang penelitian.

\section{E. Teknik Analisis Data}

Analisis Data adalah proses penyederhanaan data ke dalam bentuk yang lebih mudah dibaca dan diinterprestasikan setelah data dianalisis. Dalam penulisan skripsi ini, penulis melakukan penilitian dengan menggunakan analisis deskriftif kuantitatif dengan metode tabel frekuensi, yaitu menganalisa data dengan cara 
Asep Candra Hidayat, Pemasaran Pariwisata Kota Bogor Melalui Media Promosi Website...

mendiskripsikan atau menggambarkan data yang telah terkumpul dan menyajikannya dalam bentuk angka-angka tanpa bermaksud membuat kesimpulan yang berlaku umum.

Adapun rumus yang digunakan untuk menganalisis tabel yaitu :

$$
\mathrm{M}=\frac{\sum(\mathrm{f} . \mathrm{x})}{\mathrm{n}}
$$

Keterangan :

$\mathrm{f}=$ frekuensi

$\mathrm{M}=$ rata-rata jawaban

$\sum$ (f.x) $=$ jumlah skor kategori

$\mathrm{n}=$ jumlah responden

Hasil nilai skala interval tersebut disesuaikan dengan skala likert yang digunakan dalam penelitian. Adapun kriteria yang dimaksud adalah sebagai berikut:

\section{F. Skala Pengukuran}

Selanjutnya agar jawaban responden dapat diukur maka jawaban responden diberi skor. Dalam penelitian ini pemberian skor menggunakan skala Likert yaitu dengan menghadapkan seorang responden dengan sebuah pernyataan dan kemudian diminta untuk memberikan jawaban: "sa ngat setuju", "setuju", "ragu-ragu", "tidak setuju", "sangat tidak setuju" (Sugiyono, $2010)$.

Tabel 1. Kriteria Penilaian dan Bobot nilai setiap pertanyaan

\begin{tabular}{|l|c|}
\hline \multicolumn{1}{|c|}{ Alternatif Jawaban } & Bobot Nilai \\
\hline Sangat Baik / Sangat Setuju / Sangat Memuaskan / Selalu & 5 \\
\hline Baik / Setuju / Memuaskan / Sering & 4 \\
\hline $\begin{array}{l}\text { Kurang Baik / Kurang Setuju / Kurang Memuaskan / } \\
\text { Kadang-kadang }\end{array}$ & 3 \\
\hline Tidak Baik / Tidak Setuju / Tidak Memuaskan / Jarang & 2 \\
\hline $\begin{array}{l}\text { Sangat Tidak Baik / Sangat Tidak Setuju / Sangat Tidak } \\
\text { Memuaskan / Tidak Pernah }\end{array}$ & 1 \\
\hline
\end{tabular}

Tabel 2. Kriteria Analisis Deskripsi

\begin{tabular}{|c|l|}
\hline Rentang Kategori Skor & Penafsiran / kriteria \\
\hline $1,00-1,80$ & Sangat Tidak Baik \\
$>1,80-2,60$ & Tidak Baik \\
$>2,60-3,40$ & Cukup Baik \\
$>3,40-4,20$ & Baik \\
$>4,20-5,00$ & Sangat Baik \\
\hline
\end{tabular}

\section{G. Lokasi dan Jadwal Penelitian}

Tempat penelitian dilakukan di Kotamadya Bogor pada tanggal 22 April 2015

\section{Variabel Operasional :}


Tabel 3. Kisi-Kisi Variabel

\begin{tabular}{|c|c|c|c|c|}
\hline Variabel & Dimensi & Indikator & No Item & $\begin{array}{l}\text { Jumlah } \\
\text { Item }\end{array}$ \\
\hline \multirow{4}{*}{$\begin{array}{l}\text { Pemasaran } \\
\text { Website }\end{array}$} & $\begin{array}{l}\text { Personal } \\
\text { Relevance }\end{array}$ & $\begin{array}{l}\text { 1. Initiative (gagasan/konten } \\
\text { materi) } \\
\text { 2. Social network } \\
\text { 3. Relationship }\end{array}$ & $1,2,3$ & 3 \\
\hline & Interactivity & $\begin{array}{ll}\text { 1. } & \text { Komunikasi } \\
\text { 2. } & \text { Intesitas interaksi } \\
\text { 3. } & \text { Interaksi pasca kunjungan } \\
& \text { wisata }\end{array}$ & $1,2,3$ & 3 \\
\hline & Messege & $\begin{array}{l}\text { 1. Kemudahan akses } \\
\text { informasi wisata } \\
\text { 2. Informasi wisata lengkap } \\
\text { 3. Format informasi menarik } \\
\text { dan informatif } \\
\end{array}$ & $1,2,3$ & 3 \\
\hline & $\begin{array}{l}\text { Brand } \\
\text { familiarity }\end{array}$ & $\begin{array}{ll}\text { 1. } & \text { Dikenal dengan baik } \\
\text { 2. } & \text { Identitas Tempat Wisata } \\
\text { 3. } & \text { Ciri khas yang } \\
\text { membedakan Tempat } \\
\text { Wisata }\end{array}$ & $1,2,3$ & 3 \\
\hline
\end{tabular}

\section{HASIL DAN PEMBAHASAN}

A. Deskripsi Responden
Berdasarkan data yang diperoleh, diketahui data komposisi responden sebagai berikut:

Tabel 4. Komposisi Pegawai Berdasarkan Jenis Kelamin

\begin{tabular}{|c|c|c|}
\hline Jenis Kelamin & Keterangan & Prosentase (5\%) \\
\hline Laki - Laki & 19 Orang & 57,57 \\
\hline Perempuan & 14 Orang & 42,42 \\
\hline Total & 33 Orang & 100 \\
\hline
\end{tabular}

Sumber: Hasil Penelitian 2015

Adapun data responden berdasarkan usia adalah sebagai berikut :

Tabel 5. Komposisi Pegawai Berdasarkan Usia

\begin{tabular}{|c|c|c|}
\hline Usia & Keterangan & Prosentase \\
\hline $15-25$ & 14 Orang & 42,42 \\
\hline $25-50$ & 12 Orang & 36,36 \\
\hline$\geq 50$ & 7 Orang & 21,21 \\
\hline Total & 33 Orang & 100 \\
\hline
\end{tabular}

Sumber: Hasil Penelitian 2015

Sedangkan berdasarkan status adalah sebagai berikut : 
Asep Candra Hidayat, Pemasaran Pariwisata Kota Bogor Melalui Media Promosi Website...

Tabel 6. Komposisi Pegawai Berdasarkan Jabatan

\begin{tabular}{|c|c|c|}
\hline Status & Jumlah & Prosentase (\%) \\
\hline Pelajar/Mahasiswa & 17 Orang & 51,51 \\
\hline Karyawan & 7 Orang & 21,21 \\
\hline Guru/Dosen & 3 Orang & 09,09 \\
\hline Umum & 6 Orang & 18,18 \\
\hline Total & 33 & 100 \\
\hline
\end{tabular}

Sumber: Hasil Penelitian 2015

\section{B. Hasil Penelitian dan Pembahasan}

Berdasarkan penelitian mengenai kualitas pemasran pariwisata melalui Weadalah sebagai berikut ;

1. Initiative (Gagasan/konten Materi Promosi)
Analisis Initiative (gagasan materi promosi) berdasarkan jawaban 33 responden diperoleh hasil perhitungan skor jawaban sebagai berikut :

Tabel 7. Initiative (Gagasan/konten Materi Promosi)

\begin{tabular}{|c|c|c|c|c|c|}
\hline No & Alternatif Jawaban & $\begin{array}{l}\text { Frekuensi } \\
\text { (F) }\end{array}$ & $\begin{array}{l}\text { Bobot } \\
\text { (x) }\end{array}$ & $f(x)$ & \multirow{7}{*}{$\begin{array}{c}\mathrm{M}=\sum_{(\mathrm{x})} \mathrm{f} \\
\mathrm{n} \\
\mathrm{n}=\frac{133}{33} \\
=4,03 \\
\begin{array}{c}\text { Sangat } \\
\text { baik }\end{array}\end{array}$} \\
\hline 1 & Sangat Setuju & 9 & 5 & 45 & \\
\hline 2 & Setuju & 16 & 4 & 64 & \\
\hline 3 & Kurang Setuju & 8 & 3 & 24 & \\
\hline 4 & Tidak Setuju & 0 & 2 & 0 & \\
\hline 5 & Sangat Tidak Setuju & 0 & 1 & 0 & \\
\hline & Jumlah & 33 & & & \\
\hline
\end{tabular}

Sumber : Data Hasil Penelitian, tahun 2015

Dari tabel diatas terlihat bahwa yang menyatakan sangat setuju ada 9 orang, setuju 16 orang, kurang setuju ada 8 orang, tidak setuju ada 0 orang, dan sangat tidak setuju ada 0 orang. Sehingga rata-rata kelayakan ruang parkir sebesar 4,03 yang termasuk kategori baik.

\section{Social Network}

Analisis Social network jawaban 33 responden diperoleh hasil perhitungan skor jawaban sebagai berikut :

Tabel 8. Social Network

\begin{tabular}{|c|c|c|c|c|c|}
\hline No & Alternatif Jawaban & $\begin{array}{l}\text { Frekuensi } \\
\text { (F) }\end{array}$ & $\begin{array}{l}\text { Bobot } \\
(\mathrm{x})\end{array}$ & $f(x)$ & \multirow{7}{*}{$\begin{array}{r}\mathrm{M}=\sum_{(\mathrm{x})} \mathrm{f} \\
\mathrm{n} \\
\mathrm{n}=\frac{115}{33} \\
=3,48 \\
\text { Baik }\end{array}$} \\
\hline 1 & Sangat Setuju & 4 & 5 & 20 & \\
\hline 2 & Setuju & 10 & 4 & 40 & \\
\hline 3 & Kurang Setuju & 17 & 3 & 51 & \\
\hline 4 & Tidak Setuju & 2 & 2 & 4 & \\
\hline 5 & Sangat Tidak Setuju & 0 & 1 & 0 & \\
\hline & Jumlah & 33 & & & \\
\hline
\end{tabular}

Sumber : Data Hasil Penelitian, tahun 2015

Dari tabel diatas terlihat bahwa yang menyatakan sangat setuju ada 4 orang, setuju 10 orang, kurang setuju ada 17 orang, tidak setuju ada 2 orang, dan sangat tidak setuju ada 0 orang. Sehingga rata-rata 
Sosial Network sebesar 3,48 yang termasuk kategori baik

\section{Relationship Pemasaran}

Analisis relationship pemasaran berdasarkan jawaban 33 responden diperoleh hasil perhitungan skor jawaban sebagai berikut :

Tabel 9. Relationship Pemasaran

\begin{tabular}{|c|c|c|c|c|c|}
\hline No & Alternatif Jawaban & $\begin{array}{l}\text { Frekuensi } \\
\text { (F) }\end{array}$ & $\begin{array}{c}\text { Bobot } \\
\text { (x) }\end{array}$ & $f(x)$ & \multirow{7}{*}{$\begin{array}{c}\mathrm{M}=\sum_{(\mathrm{x})} \mathrm{f} \\
\mathrm{n} \\
\mathrm{n}=\frac{128}{33} \\
=3,88 \\
\text { Baik }\end{array}$} \\
\hline 1 & Sangat Setuju & 7 & 5 & 35 & \\
\hline 2 & Setuju & 15 & 4 & 60 & \\
\hline 3 & Kurang Setuju & 11 & 3 & 33 & \\
\hline 4 & Tidak Setuju & 0 & 2 & 0 & \\
\hline 5 & Sangat Tidak Setuju & 0 & 1 & 0 & \\
\hline \multicolumn{2}{|r|}{ Jumlah } & 33 & & & \\
\hline
\end{tabular}

Sumber : Data Hasil Penelitian, tahun 2015

Dari tabel diatas terlihat bahwa yang menyatakan sangat setuju ada 7 orang, setuju 15 orang, kurang setuju ada 11 orang, tidak setuju ada 0 orang, dan sangat tidak setuju ada 0 orang. Sehingga rata-rata relationship pemasaran sebesar 3,88 yang termasuk kategori baik.

\section{Komunikasi Pemasaran}

Analisis komunikasi pemasaran berdasarkan jawaban 33 responden diperoleh hasil perhitungan skor jawaban sebagai berikut :

Tabel 10. Komunikasi Pemasaran

\begin{tabular}{|c|c|c|c|c|c|}
\hline No & Alternatif Jawaban & $\begin{array}{l}\text { Frekuensi } \\
\text { (F) }\end{array}$ & $\begin{array}{c}\text { Bobot } \\
\text { (x) }\end{array}$ & $f(x)$ & \multirow{7}{*}{$\begin{array}{c}\mathrm{M}=\sum_{(\mathrm{x})} \mathrm{f} \\
\mathrm{n} \\
\mathrm{n}=\frac{143}{33} \\
=4,33 \\
\text { Sangat } \\
\text { Baik }\end{array}$} \\
\hline 1 & Sangat Setuju & 16 & 5 & 80 & \\
\hline 2 & Setuju & 12 & 4 & 48 & \\
\hline 3 & Kurang Setuju & 5 & 3 & 15 & \\
\hline 4 & Tidak Setuju & 0 & 2 & 0 & \\
\hline 5 & Sangat Tidak Setuju & 0 & 1 & 0 & \\
\hline & Jumlah & 33 & & & \\
\hline
\end{tabular}

Sumber : Data Hasil Penelitian, tahun 2015

Dari tabel diatas terlihat bahwa yang menyatakan sangat setuju ada 16 orang, setuju 12 orang, kurang setuju ada 5 orang, tidak setuju ada 0 orang, dan sangat tidak setuju ada 0 orang. Sehingga ratarata komunikasi pemasaran sebesar 4,33 yang termasuk kategori sangat baik .

\section{Intesitas interaksi}

Analisis Intesitas interaksi berdasarkan jawaban 33 responden diperoleh hasil perhitungan skor jawaban sebagai berikut : 
Asep Candra Hidayat, Pemasaran Pariwisata Kota Bogor Melalui Media Promosi Website...

Tabel 11. Intesitas interaksi

\begin{tabular}{|c|c|c|c|c|c|}
\hline No & Alternatif Jawaban & $\begin{array}{l}\text { Frekuensi } \\
\text { (F) }\end{array}$ & $\begin{array}{c}\text { Bobot } \\
\text { (x) }\end{array}$ & $f(x)$ & \multirow{7}{*}{$\begin{array}{c}\mathrm{M}=\sum_{(\mathrm{x})} \mathrm{f} \\
\mathrm{n} \\
\mathrm{n}=\frac{105}{33} \\
=3,18 \\
\text { Cukup } \\
\text { Baik }\end{array}$} \\
\hline 1 & Sangat Setuju & 3 & 5 & 15 & \\
\hline 2 & Setuju & 6 & 4 & 24 & \\
\hline 3 & Kurang Setuju & 18 & 3 & 18 & \\
\hline 4 & Tidak Setuju & 6 & 2 & 12 & \\
\hline 5 & Sangat Tidak Setuju & 0 & 1 & 0 & \\
\hline & Jumlah & 33 & & & \\
\hline
\end{tabular}

Sumber : Data Hasil Penelitian, tahun 2015

Dari tabel diatas terlihat bahwa yang menyatakan sangat setuju ada 3 orang, setuju 6 orang, kurang setuju ada 18 orang, tidak setuju ada 6 orang, dan sangat tidak setuju ada 0 orang. Sehingga rata-rata intesitas interaksi promosi melalui $\mathrm{Wb}$ Site sebesar 3,18 yang termasuk kategori cukup baik.

Tabel 12. Interaksi Pasca Kunjungan Wisata

\begin{tabular}{|c|c|c|c|c|c|}
\hline No & Alternatif Jawaban & $\begin{array}{l}\text { Frekuensi } \\
\text { (F) }\end{array}$ & $\begin{array}{c}\text { Bobot } \\
\text { (x) }\end{array}$ & $f(x)$ & \multirow{7}{*}{$\begin{array}{c}\mathrm{M}=\underset{(\mathrm{x})}{\sum \mathrm{f}} \\
\mathrm{n} \\
\mathrm{n}=\frac{110}{33} \\
=3,33 \\
\text { Cukup } \\
\text { Baik }\end{array}$} \\
\hline 1 & Sangat Setuju & 3 & 5 & 15 & \\
\hline 2 & Setuju & 9 & 4 & 36 & \\
\hline 3 & Kurang Setuju & 17 & 3 & 51 & \\
\hline 4 & Tidak Setuju & 4 & 2 & 8 & \\
\hline 5 & Sangat Tidak Setuju & 0 & 1 & 0 & \\
\hline & Jumlah & 33 & & & \\
\hline
\end{tabular}

Sumber : Data Hasil Penelitian, tahun 2015

\section{Interaksi Pasca Kunjungan Wisata}

Analisis interaksi pasca kunjungan wisata berdasarkan jawaban 33 responden diperoleh hasil perhitungan skor jawaban sebagai berikut :
Dari tabel diatas terlihat bahwa yang menyatakan sangat setuju ada 3 orang, setuju 9 orang, kurang setuju ada 17 orang, tidak setuju ada 4 orang, dan sangat tidak setuju ada 0 orang. Sehingga ratarata kelayakan papan informasi sebesar 3,33 yang termasuk kategori cukup baik.

\section{Kemudahan Akses Informasi}

Analisis kemudahan akses informasi berdasarkan jawaban 33 responden diperoleh hasil perhitungan skor jawaban sebagai berikut :

Tabel 13. Kemudahan akses informasi

\begin{tabular}{|c|c|c|c|c|c|}
\hline No & Alternatif Jawaban & $\begin{array}{l}\text { Frekuensi } \\
\text { (F) }\end{array}$ & $\begin{array}{l}\text { Bobot } \\
\text { (x) }\end{array}$ & $f(x)$ & \multirow{7}{*}{$\begin{array}{c}\mathrm{M}=\sum_{(\mathrm{x})} \mathrm{f} \\
\mathrm{n} \\
\mathrm{n}=\frac{142}{33} \\
=4,30 \\
\text { Sangat } \\
\text { Baik }\end{array}$} \\
\hline 1 & Sangat Setuju & 13 & 5 & 65 & \\
\hline 2 & Setuju & 17 & 4 & 68 & \\
\hline 3 & Kurang Setuju & 3 & 3 & 9 & \\
\hline 4 & Tidak Setuju & 0 & 2 & 0 & \\
\hline 5 & Sangat Tidak Setuju & 0 & 1 & 0 & \\
\hline & Jumlah & 33 & & & \\
\hline
\end{tabular}

Sumber : Data Hasil Penelitian, tahun 2015 
Dari tabel diatas terlihat bahwa yang menyatakan sangat setuju ada 13 orang, setuju 17 orang, kurang setuju ada 3 orang, tidak setuju ada 0 orang, dan sangat tidak setuju ada 0 orang. Sehingga rata-rata kemudahan akses informasi sebesar 4,30 yang termasuk kategori sangat baik.

\section{Informasi Wisata lengkap}

Analisis Informasi lengkap berdasarkan jawaban 33 responden diperoleh hasil perhitungan skor jawaban sebagai berikut :

Tabel 14. Informasi Lengkap

\begin{tabular}{|c|c|c|c|c|c|}
\hline No & Alternatif Jawaban & $\begin{array}{l}\text { Frekuensi } \\
\text { (F) }\end{array}$ & $\begin{array}{c}\text { Bobot } \\
\text { (x) }\end{array}$ & $f(x)$ & \multirow{7}{*}{$\begin{array}{c}\mathrm{M}=\sum_{(\mathrm{x})} \mathrm{f} \\
\mathrm{n} \\
\mathrm{n}=\frac{94}{33} \\
=2,85 \\
\text { Cukup } \\
\text { Baik }\end{array}$} \\
\hline 1 & Sangat Setuju & 1 & 5 & 5 & \\
\hline 2 & Setuju & 4 & 4 & 16 & \\
\hline 3 & Kurang Setuju & 17 & 3 & 51 & \\
\hline 4 & Tidak Setuju & 11 & 2 & 22 & \\
\hline 5 & Sangat Tidak Setuju & 0 & 1 & 0 & \\
\hline \multicolumn{2}{|r|}{ Jumlah } & 33 & & & \\
\hline
\end{tabular}

Sumber : Data Hasil Penelitian, tahun 2015

Dari tabel diatas terlihat bahwa yang menyatakan sangat setuju ada 1 orang, setuju 4 orang, kurang setuju ada 17 orang, tidak setuju ada 11 orang, dan sangat tidak setuju ada 0 orang. Sehingga rata-rata kelayakan ATM sebesar 2,85 yang termasuk kategori cukup baik.

\section{Format Informasi Menarik dan Informatif}

Analisis format informasi menarik dan informatif berdasarkan jawaban 33 responden diperoleh

hasil perhitungan skor jawaban sebagai berikut :

Tabel 15. Format Informasi Menarik dan Informatif

\begin{tabular}{|c|c|c|c|c|c|}
\hline No & Alternatif Jawaban & $\begin{array}{l}\text { Frekuensi } \\
\text { (F) }\end{array}$ & $\begin{array}{l}\text { Bobot } \\
\text { (x) }\end{array}$ & $f(x)$ & \multirow{7}{*}{$\begin{array}{r}\mathrm{M}=\underset{(\mathrm{x})}{\sum_{\mathrm{f}} \mathrm{f}} \\
\mathrm{n} \\
\mathrm{n}=\frac{121}{33} \\
=3,67 \\
\text { Baik }\end{array}$} \\
\hline 1 & Sangat Setuju & 5 & 5 & 25 & \\
\hline 2 & Setuju & 12 & 4 & 48 & \\
\hline 3 & Kurang Setuju & 16 & 13 & 208 & \\
\hline 4 & Tidak Setuju & 0 & 2 & & \\
\hline 5 & Sangat Tidak Setuju & 0 & 1 & & \\
\hline \multicolumn{2}{|r|}{ Jumlah } & 33 & & & \\
\hline
\end{tabular}

Sumber : Data Hasil Penelitian, tahun 2015

Dari tabel diatas terlihat bahwa yang menyatakan sangat setuju ada 5 orang, setuju 12 orang, kurang setuju ada 16 orang, tidak setuju ada 0 orang, dan sangat tidak setuju ada 0 orang. Sehingga ratarata kelayakan toilet sebesar 3,67 yang termasuk kategori baik.

\section{Dikenal Baik}

Analisis dikenal baik berdasarkan jawaban 33 responden diperoleh hasil perhitungan skor jawaban sebagai berikut 
Asep Candra Hidayat, Pemasaran Pariwisata Kota Bogor Melalui Media Promosi Website...

Tabel 16. Dikenal Baik

\begin{tabular}{|c|c|c|c|c|c|}
\hline No & Alternatif Jawaban & $\begin{array}{l}\text { Frekuensi } \\
\text { (F) }\end{array}$ & $\begin{array}{c}\text { Bobot } \\
\text { (x) }\end{array}$ & $f(x)$ & \multirow{7}{*}{$\begin{array}{c}\mathrm{M}=\sum_{(\mathrm{x})} \mathrm{f} \\
\mathrm{n} \\
\mathrm{n}=\frac{143}{33} \\
=4,33 \\
\text { Sangat } \\
\text { Baik }\end{array}$} \\
\hline 1 & Sangat Setuju & 17 & 5 & 85 & \\
\hline 2 & Setuju & 10 & 4 & 40 & \\
\hline 3 & Kurang Setuju & 6 & 3 & 18 & \\
\hline 4 & Tidak Setuju & 0 & 2 & 0 & \\
\hline 5 & Sangat Tidak Setuju & 0 & 1 & 0 & \\
\hline & Jumlah & 33 & & & \\
\hline
\end{tabular}

Sumber : Data Hasil Penelitian, tahun 2015

Dari tabel diatas terlihat bahwa yang menyatakan sangat setuju ada 17 orang, setuju 10 orang, kurang setuju ada 6 orang, tidak setuju ada 0 orang, dan sangat tidak setuju ada 0 orang. Sehingga rata-rata dikenal baik sebesar 4,33 yang termasuk kategori sangat baik

\section{Identitas Tempat Wisata}

Analisis Identitas tempat wisata berdasarkan jawaban 33 responden diperoleh hasil perhitungan skor jawaban sebagai berikut :

Tabel 17. Identitas Tempat Wisata

\begin{tabular}{|c|c|c|c|c|c|}
\hline No & Alternatif Jawaban & $\begin{array}{l}\text { Frekuensi } \\
\text { (F) }\end{array}$ & $\begin{array}{c}\text { Bobot } \\
\text { (x) }\end{array}$ & $f(x)$ & \multirow{7}{*}{$\begin{array}{c}\mathrm{M}=\sum_{(\mathrm{x})} \mathrm{f} \\
\mathrm{n} \\
\mathrm{n}=\frac{145}{33} \\
=4,39 \\
\text { Sangat } \\
\text { Baik }\end{array}$} \\
\hline 1 & Sangat Setuju & 14 & 5 & 70 & \\
\hline 2 & Setuju & 18 & 4 & 32 & \\
\hline 3 & Kurang Setuju & 1 & 3 & 3 & \\
\hline 4 & Tidak Setuju & 0 & 2 & 0 & \\
\hline 5 & Sangat Tidak Setuju & 0 & 1 & 0 & \\
\hline & Jumlah & 33 & & & \\
\hline
\end{tabular}

Sumber : Data Hasil Penelitian, tahun 2015

Dari tabel diatas terlihat bahwa yang menyatakan sangat setuju ada 14 orang, setuju 18 orang, kurang setuju ada 1 orang, tidak setuju ada 0 orang, dan sangat tidak setuju ada 0 orang. Sehingga rata-rata kualitas kemampuan (kompetensi) karyawan/customer service dalam melayani nasabah sebesar 4,39 yang termasuk kategori sangat baik.

\section{Ciri Khas yang Membedakan Tempat Wisata}

Analisis ciri khas yang membedakan tempat wisata berdasarkan jawaban 33 responden diperoleh hasil perhitungan skor jawaban sebagai berikut :

Tabel 18. Ciri Khas yang Membedakan Tempat Wisata

\begin{tabular}{|c|c|c|c|c|c|}
\hline No & Alternatif Jawaban & $\begin{array}{l}\text { Frekuensi } \\
\text { (F) }\end{array}$ & $\begin{array}{l}\text { Bobot } \\
\text { (x) }\end{array}$ & $f(x)$ & \multirow{7}{*}{$\begin{array}{c}\mathrm{M}=\sum_{(\mathrm{x})} \mathrm{f} \\
\mathrm{n} \\
\mathrm{n}=\frac{152}{33} \\
=4,61 \\
\text { Sangat } \\
\text { Baik }\end{array}$} \\
\hline 1 & Sangat Setuju & 20 & 5 & 100 & \\
\hline 2 & Setuju & 13 & 4 & 52 & \\
\hline 3 & Kurang Setuju & 0 & 3 & 0 & \\
\hline 4 & Tidak Setuju & 0 & 2 & 0 & \\
\hline 5 & Sangat Tidak Setuju & 0 & 1 & 0 & \\
\hline & Jumlah & 33 & & & \\
\hline
\end{tabular}

Sumber : Data Hasil Penelitian, tahun 2015 
Dari tabel diatas terlihat bahwa yang menyatakan sangat setuju ada 20 orang, setuju 13 orang, kurang setuju ada 0 orang, tidak setuju ada 0 orang, dan sangat tidak setuju ada 0 orang. Sehingga rata-rata ciri khas yang membedakan tempat wisata sebesar 4,61 yang termasuk kategori sangat baik.

\section{Rekapitulasi Pemasaran Pariwisata Kota Bogor melalui Web Site \\ Rekapitulasi keseluruhan pembahasan} mengenai analisis Pemasaran Pariwisata Kota Bogor melalui Web Site dapat diketahui pada tabel dibawah ini :

Tabel 19. Analisis Rekapitulasi Pemasaran Pariwisata Kota Bogor melalui Web Site

\begin{tabular}{|c|l|c|l|}
\hline No & \multicolumn{1}{|c|}{ Indikator } & $\begin{array}{c}\text { Rata- } \\
\text { rata }\end{array}$ & \multicolumn{1}{|c|}{ Hasil } \\
\hline & \multicolumn{1}{|c|}{ Indikator } & & \\
\hline 1 & Initiative (gagasan/konten materi promosi) & 4,03 & Sangat Baik \\
\hline 2 & Social network & 3,48 & Baik \\
\hline 3 & Relationship pemasaran & 3,88 & Baik \\
\hline 4 & Komunikasi pemasaran & 4,33 & Sangat Baik \\
\hline 5 & Intesitas interaksi & 3,18 & Sangat Baik \\
\hline 6 & Interaksi pasca kunjungan wisata & 3,33 & Cukup Baik \\
\hline 7 & Kemudahan akses informasi wisata & 4,30 & Sangat Baik \\
\hline 8 & Informasi wisata & 2,85 & Cukup Baik \\
\hline 9 & Format informasi menarik dan informatif & 3,67 & Baik \\
\hline 10 & Dikenal baik & 4,33 & Sangat Baik \\
\hline 11 & Identitas tempat wisata & 4,39 & Sangat Baik \\
\hline 12 & Ciri khas yang membedakan & 4,61 & Sangat Baik \\
\hline & Tempat wisata & & \\
\hline & & 3,87 & Baik \\
\hline & Rata-rata skor & 2015 & \\
\hline
\end{tabular}

Sumber : Data Hasil Penelitian, tahun 2015

Berdasarkan hasil dari Tabel di atas, terlihat bahwa rata-rata Pemasaran Pariwisata Kota Bogor melalui Web Site sudah sangat baik, hal tersebut terlihat dari nilai skor rata-rata kualitas pelayanan sebesar 3,87 yang termasuk kategori baik.

\section{Pembahasan}

Dari hasil penelitian di atas, terlihat bahwa secara umum Pemasaran Pariwisata Kota Bogor melalui Web Site sudah baik, karena semua komponen penilaian telah memenuhi standar penilaian yang baik atau sangat baik dari masyarakat, dalam hal ini wisatawan yang telah maupun yang akan berkunjung ke tempat-tempat wisata di kota Bogor.
Namun demikian masih ada beberapa komponen penilaian yang perlu ditingkatkan diantaranya adalah faktor :

1. Interaksi pasca kunjungan wisata, yang dalam penilaian masyarakat masih dibawah nilai lainnya yaitu sebesar 3,33 atau cukup

2. Informasi wisata lengkap yang dalam penilaian masyarakat masih dibawah nilai lainnya yaitu sebesar 2,85 cukup

Dua komponen penilaian tersebut dapat ditingkatkan agar hasilnya lebih baik lagi.

Upaya peningkatan tersebut berupa :

1. Untuk Interaksi pasca kunjungan wisata perlu ditingkatkan melalui peningkatan pengelolaan konten web yang memuat pola interaksi, komunikasi dan informasi yang baik berupa menyedian ruang/konten 
Asep Candra Hidayat, Pemasaran Pariwisata Kota Bogor Melalui Media Promosi Website...

masukan, saran dan kritikan yang lebih interaktif

2. Untuk informasi wisata perlu ditingkatkan lagi dengan menyajikan materi/konten informasi yang lengkap, yang up todate dan dengan informasi yang lebih menarik.

Mengingat jaman senantiasa terus berubah dan berdampak terhadap perubahan kuantitas dan kualitas wisata di Kota Bogor, maka sudah sepantasnya Pemda Kota Bogor, terus menerus melakukan perbaikan, pembenahan dan peningkatan kualitas web, agar mampu menyelaraskan diri dengan tuntutan jaman serta kebutuhan para wisatawan, baik wisatawan local, domestic, nasional, regional maupun mancanegara. Apalagi di era milenimum ke-3 ini, laju peningkatan jumlah penduduk bertambah begitu pesat, perubahan jaman berjalan sangat cepat, persaingan wisata yang begitu ketat, sehingga untuk memenangkan persaingan wisata perlu terobosan dan inovasi yang lebih baik lagi bagi untuk memaksimalkan upaya promosi wisata. Upaya promosi yang paling tepat di era sekarang adalah era digital onlie (e-commerce) melalui pengelolaan web site yang tepat, akurat, lengkap dan menarik.

\section{Kesimpulan Dan Saran}

\section{A. Kesimpulan :}

Pemasaran Pariwisata Kota Bogor melalui Web Site sudah sangat baik, hal tersebut terlihat dari nilai skor rata-rata kualitas pelayanan sebesar 3,87 yang termasuk kategori baik. Namun demikian masih ada beberapa komponen penilaian yang perlu ditingkatkan yaitu "Interaksi Pasca Kunjungan Wisata" serta "Informasi Wisata Lengkap“

\section{B. Saran :}

1. Interaksi pasca kunjungan wisata perlu ditingkatkan melalui peningkatan pengelolaan konten web yang memuat pola interaksi, komunikasi dan informasi yang baik berupa menyedian ruang/konten masukan, saran dan kritikan yang lebih interaktif

2. Iinformasi wisata perlu ditingkatkan lagi dengan menyajikan materi/konten informasi yang lengkap, yang up todate dan dengan informasi yang lebih menarik.

\section{Daftar Pustaka}

Akkanat, Kaan, 2015, Communication and Interaction on Instagram. a Psychological Science Perspective, BOD Third Party Titles.

Bahri, Rayza Ardian, 2012, Analisis Pengaruh Endorser Di Social Media Terhadap Keputusan Pembelian Produk Dengan Metode AISAS (Studi Kasus pada Telkomsel), Skripsi Tekom University, Bandung.

Benhardt, Mays dan Hall, 2012, Social Marketing At The Right Place And Right Time With New Media, Journal of Social Marketing, Vol.2: Issu. 2:nPages: 130137. Emerald Group.

Daryanto, 2011, Sari Kuliah Manajemen Pemasaran. Bandung : PT. Sarana Tutorial Nurani Sejahtera.

Gunelius, 2011. 30 Minute Social Media Marketing: Step by StepTechniques to Spread the Words about your Business, USA: McGraw-Hill.

Hermawan, Agus. 2012, Komunikasi Pemasaran. Jakarta : Erlangga.

Junia, Meri, 2015, Hubungan antara Iklan di Media Sosial dengan Minat Beli Konsumen Studi Korelasi Mengenai Hubungan antara Daya Tarik Pesan Iklan di Fanpage Facebook Lazada Indonesi dengan Minat Beli Konsumen dari Mahasiswa Sekolah Tinggi Ilmu Komunikasi Bandung, http://hdl.handle.net/123456789/370. html

Kotler dan Keller. 2010. Marketing Management 13. New Jersey: Pearson Prentice Hall, Inc.

Kotler dan Keller. 2012, Marketing Management 13. New Jersey: Pearson Prentice Hall, Inc. 
Kotler, Philip. 2005. Manajemen Pemasaran Jilid Satu. Jakarta: Indeks

Laudon, Kenneth C dan Jane P. Laudon. (2008). Sistem Informasi Manajemen:

Laudon, Kenneth C., Laudon, Jane P., 2005. "Sistem Informasi Manajemen: Mengelola Perusahaan digital:, Edisi Delapan. Penerbit Andi, Yogyakarta.

Madcoms. 2008. "Sistem Informasi Manajemen, Jilid 10". Penerbit Andi, Yogyakarta
Prof.Hunziker, Kraft. 1942. Definisi-definisi Wisatawan. PT.Gramedia. Jakarta

Sukirno, Sadono. 1985. Ekonomi Pembangunan. Jakarta : LPEF-UI Bima Grafika

Sunaryo, Bambang, 2013 Kebijakan Pembangunan Destinasi Pariwisata : Konsep dan aplikasinya di Indonesia, Yogyakarta; Gava Media.

Spillane. James. 1987. "Ekonomi Pariwisata". Kanisius, Yogyakarta. 